学術論文

\title{
全波整流コイルと歯のタオレを用いたベアリングレスモータ
}

\section{Discussion of Bearingless Motor with Full Wave Rectified Circuit Coil and Inclined Teeth}

\author{
立花 邦彦 ${ }^{* 1}$ (学生員), 岡 宏一 ${ }^{* 1}$ (正員)
}

Kunihiko TACHIBANA (Stu. Mem.), Koichi OKA (Mem.)

\begin{abstract}
This paper represents the research finding of levitation and rotation control on bearingless motor with rectified circuit coil and inclined teeth. Rectified circuit coils are functioned as transmitting and receiving coil of wireless electric power transmission, and supply direct current to rotor coils. Rotor coils are used as rotor magnets not using permanent magnets. Even if horizontal force of magnet is strong, unless vertical force of magnet exists, a rotor does not levitate. So as to generate vertical force, the tip form of rotor and stator is made to incline and levitation force (vertical force) is acquired using this inclination.
\end{abstract}

Keywords: bearingless motor, rectified circuit coil, wireless power transmission, inclination of tooth, levitation force

\section{1 緒言}

これまでに多くのベアリングレスモータが提案さ れているが，固定子または回転子に永久磁石を使用し ているものがほとんどである[1-5]。このため, 高温環 境下での使用はできず，永久磁石には経年変化や外部 からの磁界によって減磁が生じる。近年, $100{ }^{\circ} \mathrm{C}$ 超える温度まで使用可能な永久磁石が入手可能[6-8]と なったものの, その他の問題は未だ解決されていない。

著者らは永久磁石を使用しない半波整流式の整流 コイルを用いたベアリングレスモータを提案してきた が[9-12], 発生力や効率の向上が課題となっていた。

この課題解決のため, 全波整流型の整流コイルでの 電力伝送，鉄心の歯の形状に関しての提案を行う。

回転子で発生する磁力は整流コイルに供給される 電力により決まってしまうため, 安定した浮上や回転 を行うためには，多くの電力を供給する必要がある。 また, 回転子の磁力は永久磁石を使用寸る場合と比較 して小さくなるが，小さな磁力で回転子を浮上させる ためには, 効率的に磁気支持力（ $\mathrm{Z}$ 軸方向の浮上力） を得る必要がある。このためには歯の端部 Z 軸にタオ レ(傾き)が存在することが有効であると考えられる。 レーザ切断の場合, タオレが必然的に存在するが, こ れを利用寸ることにより，歯の端部形状が得られる。

本論文では全波整流式の整流コイルを用いたベア

連絡先：立花 邦彦, $\bar{T} 782-8502$ 高知県香美市土佐山田 町宮ノ口 185, 高知工科大学 大学院 基盤工学専攻, e-mail: 156006p@gs.kochi-tech.ac.jp

${ }^{* 1}$ 高知工科大学
リングレスモータの浮上と回転に必要な電力伝送方法, 歯の端部のタオレによる浮上力の発生, 回転力の発生, および浮上と回転の制御手法に関して, 基本原理と実 施したシミュレーション，実験結果について述べる。

\section{2 整流コイルの原理}

整流コイルは電磁誘導によって得られる起電力を, ダイオードを使用し直流化することで，コイルに発生 する磁極を固定するものであり, 提案する電力伝送コ イルを用いた全波整流式を Fig.1 に示す。交流電流を 電力伝送コイル一次側に印加することで，二次側には 交流の誘起起電力が発生するが，ブリッジダイオード により回転子コイルには一方向の電流が流れるため, 回転子コイル両端には固定された磁極が現れる。した がって, 回転子に永久磁石を取り付けた場合と同様に 扱うことができるようになり，例えば回転子の両端を $\mathrm{N}$ 極となるように磁極を固定できる。

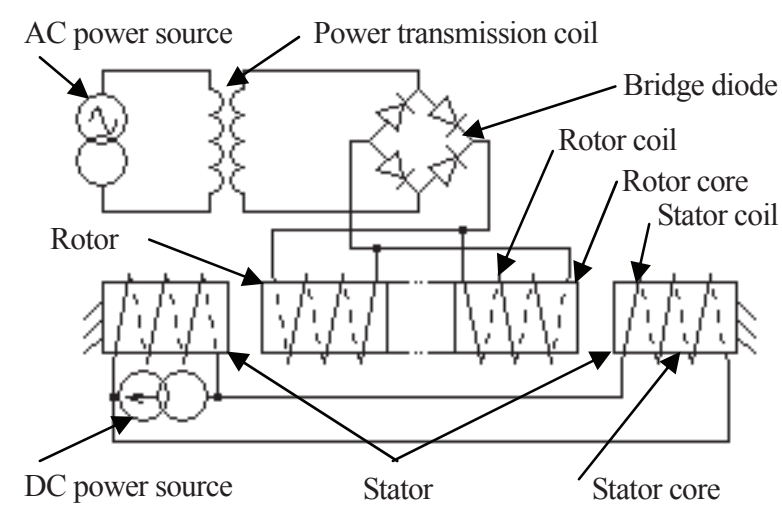

Fig. 1 Schematic of full wave rectification type. 


\section{3 整流コイルを用いたベアリングレスモータ}

\section{1 構造}

ベアリングレスモータの構造を Fig.2 に示す。ベア リングレスモータは能動的に制御する軸数により 1 〜 5 軸制御型に分類されるが， 2 軸制御型とすることで 構造および制御を簡素化できると考えた。また，永久 磁石を使用しないことから, 回転子の大きな磁力を得 るために, 歯の数を増やすことで対忘することとした。 さらに，回転子により多くの電力を供給可能とするた め，全波整流式とした。

固定子および回転子鉄心は扁平形状であり，軸方向 には Fig.2(b)に示すように短く二層構造である。一層当 たり, 固定子の歯は 24 個, 回転子の歯は 32 個である。

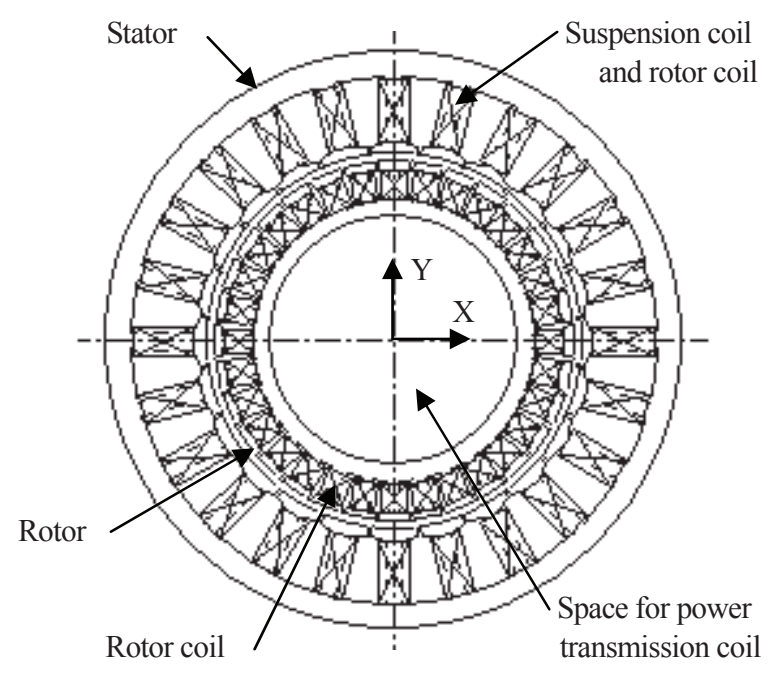

(a) Top view

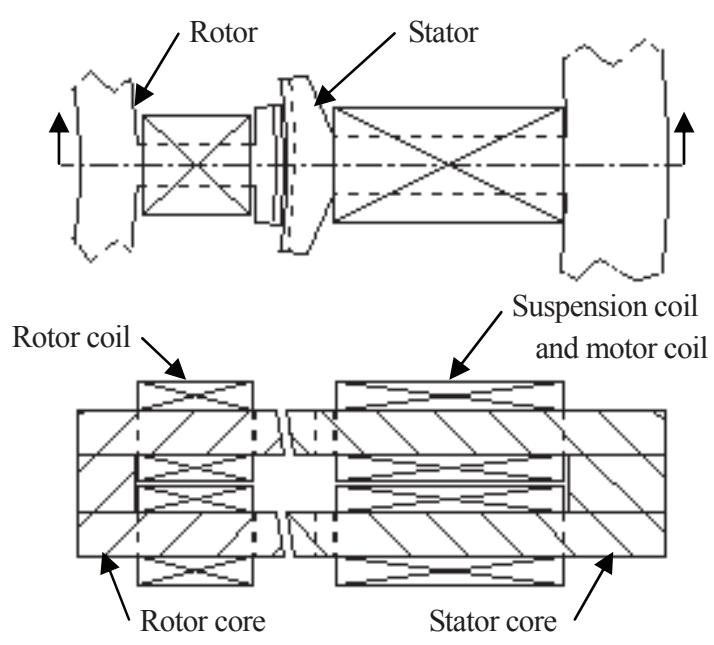

(b) Detail of teeth

Fig. 2 Schematic of bearingless motor.
固定子には支持コイルと回転コイルが，回転子には回 転子コイルが巻かれる。また，回転子鉄心の内側に電 力伝送コイルを配置する。

\section{2 磁気支持力発生原理}

固定子と対向する回転子の磁極は，一層では全て $\mathrm{N}$ 極または $\mathrm{S}$ 極となるモノポーラ型となるように回転子 コイルを接続する。上側層において，回転子の歯を $\mathrm{N}$ 極とすれば，固定子の支持コイルには $\mathrm{S}$ 極となるよう に電流を流す。電力伝送コイルに励磁電流を流すこと で回転子コイルに磁極が発生し，固定子コイルに支持 電流を流すことで，回転子，固定子間に吸引力が発生 し，これが支持力となる。励磁電流を一定とし，固定 子支持コイル全てに同じ值の電流を流したとき，回転 子が固定子から受けるX軸およびY軸方向の力のベク トルを全周にわたって積分すると 0 となるため，回転 子軸は固定子軸の中心に位置することになる。

Fig.3 に示すように固定子支持コイルを, $\mathrm{u}$ 軸, $\mathrm{v}$ 軸, $\mathrm{w}$ 軸の 3 軸となるように配置すると，XY 座標での位 置を U v w座標に置き換えることができる。回転子の $\mathrm{X}$ 軸， $\mathrm{Y}$ 軸方向の変位を検出し，これをもとに 2 相 3 相変換を行い, 固定子の $\mathrm{u}, \mathrm{v}, \mathrm{w}$ 軸の磁気支持力（供 給する電流值）を調整することで，それぞれの軸方向 の力の大きさを変えることができ，力のベクトル和に より任意の半径方向に力を発生できる。この力の不均 衡により回転子の半径方向の位置制御が可能となる。

Z 軸について磁気支持力の発生原理を Fig.4 に示す。 一般的に回転子と固定子の歯の端部は回転軸に対して 平行とするが，この方法では回転軸方向に短く磁力が

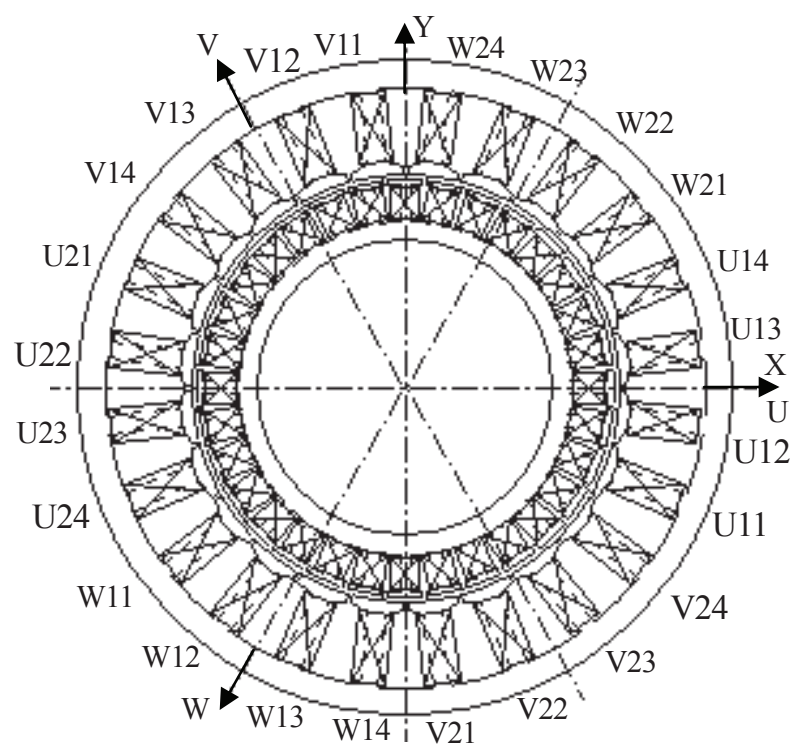

Fig. 3 Principle of radial suspension force generation. 


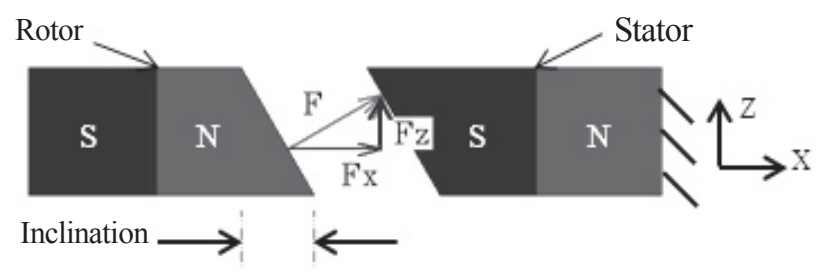

Fig. 4 Principle of axial suspension force generation.
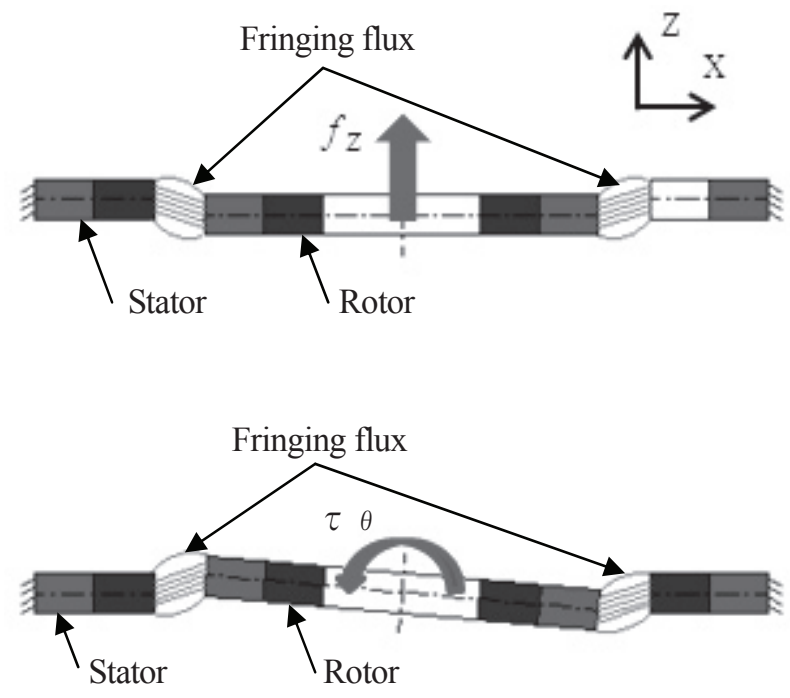

(b) Tilting displacement

Fig. 5 Principle of axial and tilting restitutive force generation.

小さな電磁石の場合，十分な支持力を得ることが難し い。そこで， Z 軸に対してタオレを有する形状の歯の 端部とし， $\mathrm{Z}$ 軸の支持力を向上することとした。空隙 部の磁束線の向きは着磁方向の端部面に垂直であるた め, Fig.4に示すように右斜め上向きの力 Fが発生する。 この力はX軸方向と Z 軸方向の力のベクトル合成であ り， Z 軸方向の力が発生することになる。

Fig.5 に軸方向および傾き方向に変位が生じた場合 について復元力の発生原理を示寸。回転子が平衡位置 から変位すると, 回転子および固定子の固定された磁 極の吸引力により, 軸方向の復元力 $f_{\mathrm{Z}}$, 傾き方向の復 元力 $\tau_{\theta}$ が発生する。このとき歯端部のフリンジング 磁束が主な復元力を発生し, 回転子は受動的に安定す ることになる。回転子は薄くて大きな直径なものが復 元方向の剛性が高くなるが, 設計時には回転子の質量 と磁力のバランスを考慮する必要がある。

\section{3 回転力発生原理}

反発力で回転させるとすると, 回転子に Z 軸下向き 力が発生し浮上力が低下寸るため吸引力を利用する。

Fig.6 で示す位置に固定子, 回転子があり, 支持電流に

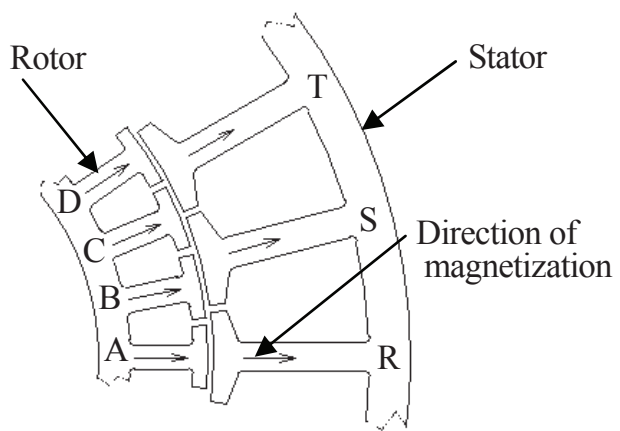

Fig. 6 Principle of rotation force generation.

より矢印の向きに励磁されているとする。このとき回 転子 B は歯の中心は回転子 $\mathrm{C}$ よりも固定子 $\mathrm{S}$ に近く, 固定子 $\mathrm{S}$ と対向する歯の面積も大きいため, 固定子 $\mathrm{S}$ に回転電流を印加すると, 固定子 $\mathrm{S}$ と回転子 $\mathrm{B}, \mathrm{C}$ と の間の磁束が増加するが, 回転子 B を流れる磁束は回 転子 C よりも多くなる。したがって固定子 $\mathrm{S}$ との間で 生じる力は, 回転子 B が C よりも大きく, 力に差が生 じる。回転軸対称位置でも同じ力が発生しており，半 径方向の力は偶力により相殺され，回転子には回転方 向のみの力が加わる。回転子 B に加わる力が $\mathrm{C}$ よりも 大きいため, この差が回転子を反時計回りに回寸力と なり, 回転子 $\mathrm{B}$ と固定子 $\mathrm{S}$ が正対する位置まで回転す る。固定子 $\mathrm{S}$ への回転電流の印加を停止し, 固定子 $\mathrm{T}$ に回転電流を印加すると, 固定子 $\mathrm{T}$ と回転子 $\mathrm{C}, \mathrm{D}$ と の間で, 同様な力が発生し回転子 $\mathrm{C}$ は固定子 $\mathrm{T}$ と正対 する位置まで回転する。これを順次繰り返すことで, 回転子を回転することができる。

\section{4 固定子コイル}

固定子には磁気支持力を発生させるための支持コイ ルと, 回転のために必要な磁力を発生させるための回 転コイルが必要となる。1つのコイルに両方の機能を 持たせるとすると, 使用線材径を大きくしなければな らず，コイル径が大きくなってしまう。そこで，使用 線材径を小さくし，2つのコイルを並列巻きとするこ とで，巻き厚みが極力小さくなるようにする。

固定子コイルの配置を Fig.7 に示寸。Fig.7 で半径方 向内側が支持コイル，外側が回転コイルである。説明 上，固定子に巻くコイルは 1 つの歯に集中巻きコイル を2つ並べたように示しているが，実際には並列巻で あるため，1つのコイルのようになる。支持コイルに は直流電流，回転コイルには矩形波電流を供給する。 回転制御は 3 相で行う計画であり，一層での 1 相当た りの固定子のコイル数は 8 となる。 


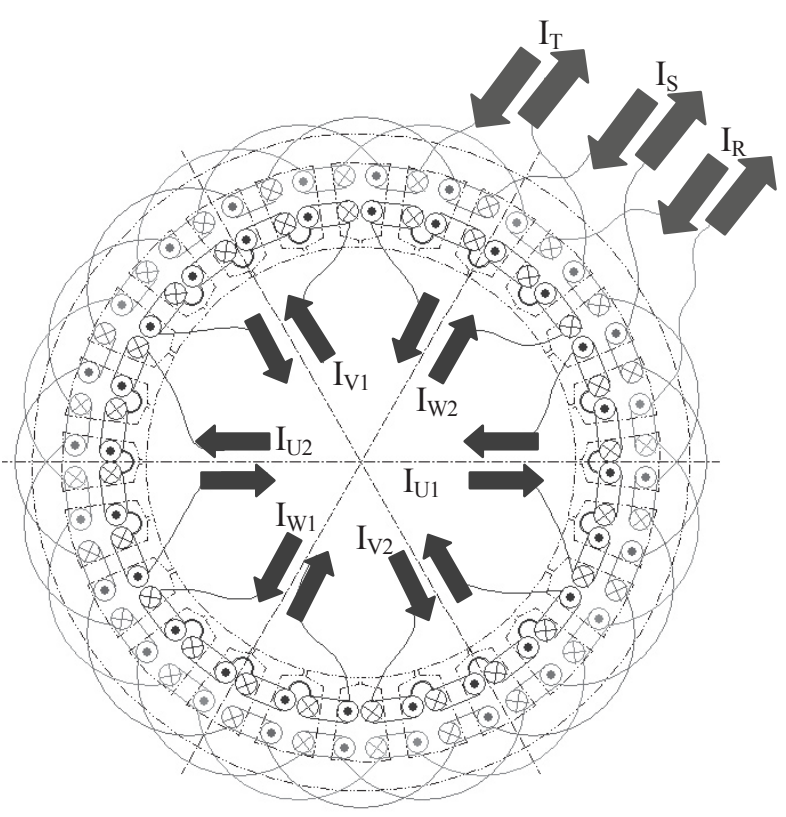

Fig. 7 Schematic of levitation and motor coil.

\section{4 ベアリングレスモータの設計}

\section{1 回転子, 固定子の材料と加工}

モータでは鉄損を低減するため, 鉄心の材料として 薄板電磁鋼板が一般的に用いられるが，機械的強度が 問題になることがある。一方, 直流電磁石では鋳鉄, 軟鉄板等の鉄塊が用いられ，機械的強度や加工性に優 れている。今回，回転子コイルおよび固定子の支持コ イルには直流電流が供給されるため、鉄心の材料とし て軟鉄板を使用することとした。

鉄心の加工方法として，レーザ加工，ワイヤ放電加 工， NC 加工等が考えられる。この中で 2 次元レーザ 加工では切断面にタオレが生じることに着目した。板 材厚みや加工機, 加工時の設定等により違いがあるも のの，5mm 厚みの軟鉄板であれば，Fig.8 に示すよう に $0.5 \mathrm{~mm} \sim 0.8 \mathrm{~mm}$ 程度（近年の加工機では $0.1 \mathrm{~mm} \sim$ $0.2 \mathrm{~mm}$ 程度) のタオレが生じる。

\section{2 浮上力}

回転子の質量は計画している寸法で約 $0.8 \mathrm{~kg}$ である ため, 7.84N 以上の浮上力が必要となる。回転子の歯 の数は一層当たり 32 歯であり，二層あるので合計 64 歯であるから，回転子の歯 1 個当たり約 $0.123 \mathrm{~N}$ の Z 軸方向の力が必要となるため, まずタオレと力の関係 を求める。固定子コイルの支持電流, 電力伝送コイル の励磁電流を計画值の $75 \%$ とし, 歯のタオレ角度によ る発生する力の違いを計算した結果を Fig.9 に示す。

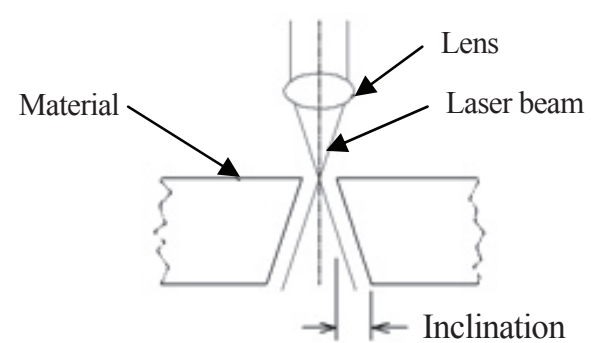

Fig. 8 Inclination by laser beam cutting.

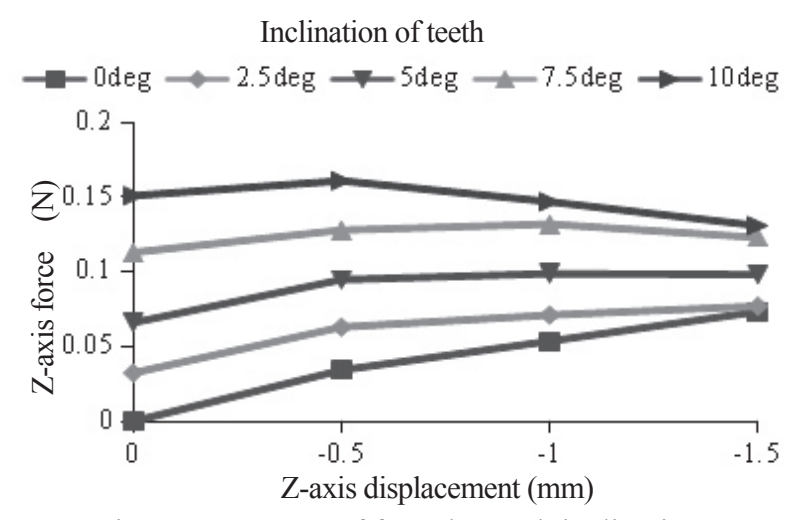

Fig. 9 Compare of force by teeth inclination

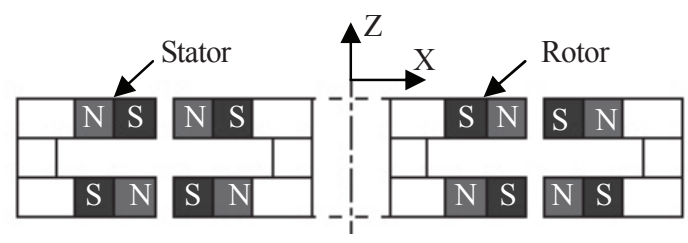

Fig.10 Magnetization direction.

浮上に必要な力を発生できるのは，歯のタオレが

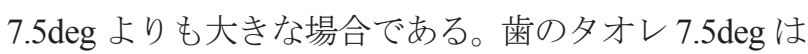
鉄心厚みを $4.5 \mathrm{~mm}$ とすると $0.6 \mathrm{~mm}$ に相当する。歯の タオレ量が大きくなるにしたがい, $\mathrm{Z}$ 軸変位が $0 \mathrm{~mm}$ の 時の力は大きくなるが，Z 軸変位がー $0.5 \mathrm{~mm}$ を越える と, ほとんど増加しないか，または小さくなる。これ はフリンジング磁束による力の減少と考える。

\section{3 回転子の磁極}

磁気支持力を得るのに，吸引力と反発力とが考えら れるが，反発力を使用する場合，反発力と垂直な方向 に不安定であることから，吸引力を使用することとし た。磁束の流れを考慮し, Fig.10 に示すように全ての 対向面で吸引力が得られる磁極が発生するように, 各 コイルを巻き電流を供給する。

\section{4 歯の形状}

回転子の回転角による磁力（支持力）の変動を小さ くするため, 歯端部のテーパを考える。テーパ寸法を 
変え, 固定子中心間を 1 度ごとに回転子を回転させ, 磁力の計算を行った。回転子, 固定子ともに, 深さ $0.5 \mathrm{~mm}$, 長さ $1 \mathrm{~mm}$ の場合に力の変動が一番少なかった。 この場合とテーパ無しの場合について, 力の比較を Fig.11 に示す。磁力の変動が小さくなっており, 歯の テーパが有効に機能していることがわかる。

\section{5 固定子コイルの巻き方}

固定子に支持コイルと回転コイルを巻くことは既 に述べた。回転コイルには矩形波電流を流すことから， コイルのインダクタンスが小さな值であれば，電源容 量が小さくてすむ。コイルを巻く方法として Fig.12に 示寸 3 つの方法が考えられる。Fig.12(c)に示寸 $2 つ の$ コイル線を並列に巻く方法が，インダクタンスが一番 小さいことから，並列巻きとすることとした。また， コイルの巻き長さが長くなると磁化力 $(\mathrm{AT} / \mathrm{m})$ が小さく なるため, 巻き長さを極力短くする。

\section{6 回転子への電力伝送}

これまでに提案してきた半波整流式は[10], 鉄心に 支持磁束, 励磁磁束, および回転磁束が重乗された磁 束が流れるため, これらの総磁束が多いと鉄心に磁気 飽和の問題が生じるため, 伝送電力に制約があった。

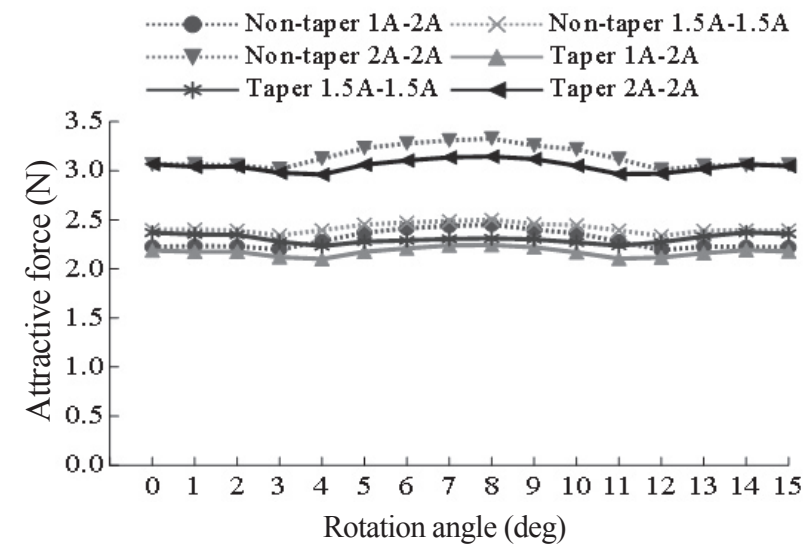

Fig. 11 Compare of attractive force with teeth taper.

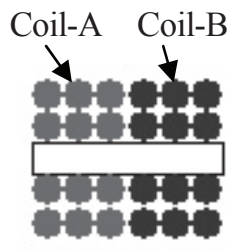

(a) Concentrated

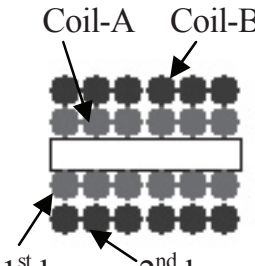

$1^{\text {st }}$ layer $2^{\text {nd }}$ layer $1^{\text {st }}$ layer $2^{\text {nd }}$ layer

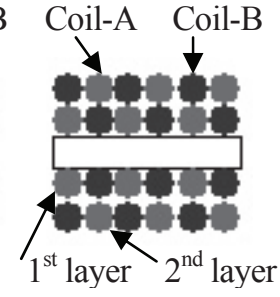

(c) Parallel
Fig.12 Coil winding method
この問題を解決するため, 回転子コイルを直接励磁 する方法ではなく，間接的に回転子コイルに電力を伝 送する方法として，Fig.13 に示す電力伝送用コイルを 回転子中央に付加することとした。

電力伝送コイルは伝送効率を上げるため，コイルの 巻き方をスパイダー巻きとし，さらに一次側にはコン デンサによる共振を用いる。負荷抵抗（回転子コイル の抵抗）とコイル間隙を変化させた場合の，電力伝送 効率を測定した結果を Fig.14 に示す。回転子コイルの 抵抗の計算值は約 $5.5 \Omega$ であり, 図から $80 \%$ 以上の伝 送効率を得られていることが分かる。全波整流である から，回転子コイルに流れる電流の平均值は，半波整 流式の 2 倍となる。また, 供給可能な電力の最大值は, 直接励磁と異なりコイル線材の許容電流值で決まるた め, 直接励磁よりも多くの電力を回転子コイルに供給 することが可能となる。

\section{7 浮上, XY 位置制御}

回転子の Z 軸浮上位置は, 大きな変位が生じなけれ ば，受動的に初期位置に復元するため，初期浮上位置 を任意に設定可能な制御とすればよい。一方，回転子 の XY 軸位置については，変位センサを用いて位置誤 差を計測し，その值により制御を行う必要がある。

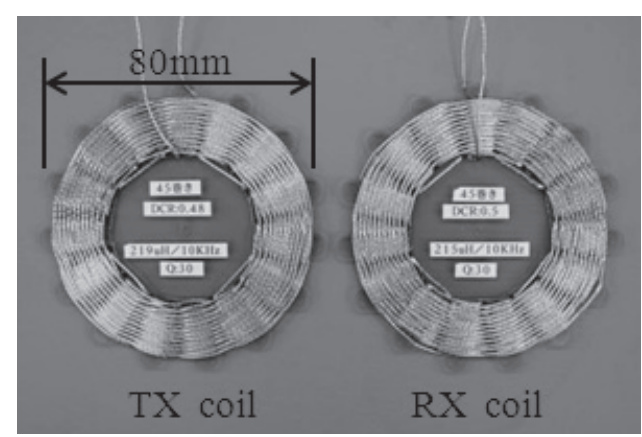

Fig. 13 Wireless power transmitting coil.

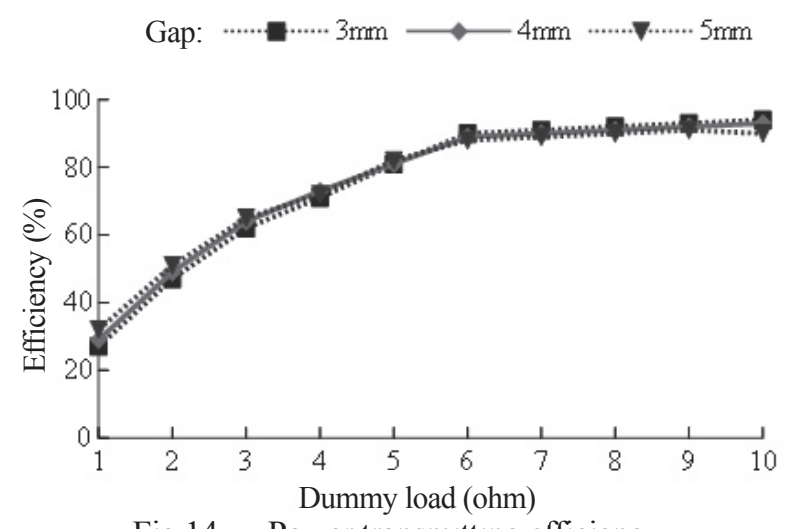

Fig.14 Power transmittıng efficiency 


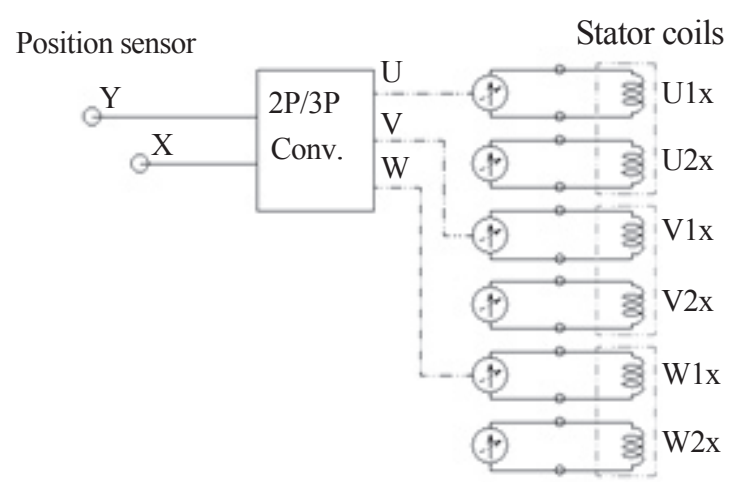

Variable current source

Fig. 15 Control circuit of floatation and XY position.

Fig. 15 に示すように, 変位センサの信号を 2 相 3 相 変換し, UVW の 3 軸に該当するコイルの電流を制御 する。各軸のコイル配置は Fig.3 で示したものとし, Fig.15 での U2x, V2x, W2x のコイル電流は初期浮上 位置まで浮上させたあとは一定值とする。U1x, V1x, $\mathrm{W} 1 \mathrm{x}$ のコイル電流は浮上させたあと, XY 位置誤差に より変化させる。

\section{8 回転制御}

すでに 3.3 項で説明したように，固定子の強い磁力 を持つ歯を移動させることで，回転子との間に力が働 き，回転子が回転する。このことから，回転子に永久 磁石を使用したステッピングモータと, 同様な方法で 回転制御を行うことができる。したがって、何相制御 でも可能であるが, 汎用 3 相インバータ IC との組合せ により回転制御を行うことが可能なように，3相制御 を行うこととした。回転制御電流をコイルに供給する ため, Fig.16に示すように回転用矩形波信号により, R, $\mathrm{S}, \mathrm{T}$ 各相のスイッチ素子を $\mathrm{ON}, \mathrm{OFF}$ することで，各 相のコイルに供給される電流が制御される。コイル電 流は有りか無しであり, 向きは一方向のみとなる。

\section{5 結言}

永久磁石を使用せず、電力伝送コイルと全波整流回 路を用い，鉄心の歯にタオレを有することが特徵であ る，2 層扁平モノポーラ型のベアリングレスモータを 提案した。電力伝送コイルにより効率良く回転子に電 力を送ることが可能であること，また，回転子と固定 子対向面の歯のタオレを用いることで, 効率的に浮上 力を得られることを, シミュレーション結果から示し た。これらのことから, コイル線材に高耐熱線を使用 することで，永久磁石を使用したモータよりもさらに

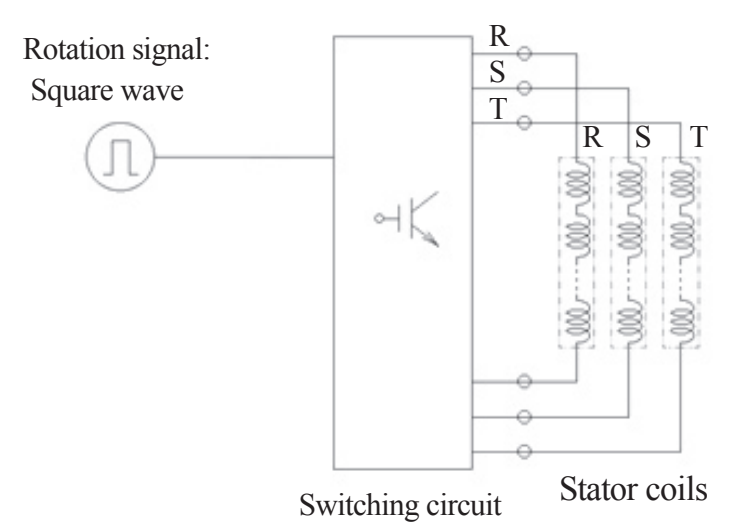

Fig. 16 Control circuit of rotation.

高温下での使用が可能なベアリングレスモータを具現 化することが可能であると考える。

今後は, 実験用モータを試作し, 提案内容の検証を 行うとともに，歯の間隙やタオレの最適值，浮上力を 簡単に算出する方法などについて研究をさらに進める。 (2014 年 3 月 11 日受付)

\section{参考文献}

[1] 松田, 喜多, 増澤, 岡田, 人工心臓用磁気浮上モ一夕の 研究, 日本機械学会, D\&D 2000 CD-ROM 論文集, 2000.

[2] 金箱, 小西, 岡田, ローレンツ力を利用したラジアルセ ルフベアリングモータの開発, 日本機械学会, D\&D 2000 CD-ROM 論文集, 2000.

[3] 大井, 松橋, 野村, ワイドギャップ構造ベアリングレス モ一夕の特性測定, 明電時報, 通巻 331 号,pp. 35-40, 2011.

[4] P. Karutz, T. Nussbaumer, W. Gruber and J.W. Kolar, Novel Magnetically Levitated Tow-Level Motor, IEEE Transactions on Mechatronics, Vol. 13, No. 6, pp. 658-668, 2008.

[5] 杉本, 朝間, 千葉, トロイダル巻を用いた多極シンコク エントポール型ベアリングレスモータの磁気支持特性, 電気学会論文誌D, Vol. 132, No. 12, pp. 1112-1120, 2012.

[6] http://www.neomag.jp/

[7] http://www.magfine.co.jp/

[8] http://www.26magnet.co.jp/

[9] K. Oka, Bearingless Motor with Rectifier Circuits, Proc. of the $8^{\text {th }}$ Int. Symposium on Magnetic Bearings, pp. 271-276, 2002.

[10] 荒谷, 岡, 陳, 整流回路を用いたベアリングレスモータ の開発一回転機構に関する考察一, 日本 AEM 学会, 第 17 回「電磁力関係のダイナミクス」シンポジウム 講演論文集，pp.493-496, 2005 .

[11] 佐伯, 岡, 楠川, 整流コイルを用いたベアリングレス モータのロータ形状の改善, 日本設計工学会四国支部, 平成 21 年度研究発表講演会講演論文集, pp7-10,2010

[12] 立花, 岡, 整流コイルを用いたベアリングレスモータの ロータ浮上, 日本機械学会, D\&D 2012 USB 論文集, 2012 